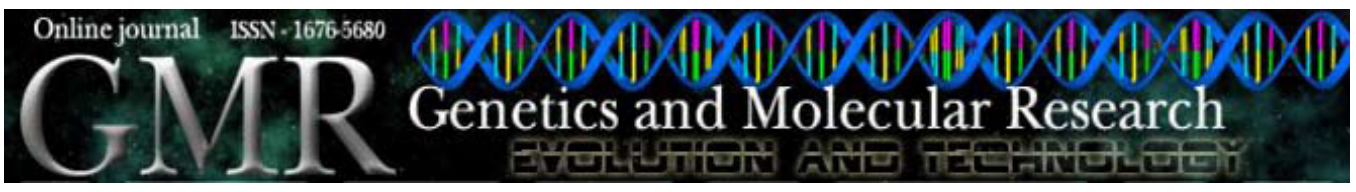

\title{
Isolation of genomic DNA from defatted oil seed residue of rapeseed (Brassica napus)
}

\author{
M. Sadia ${ }^{1}$, M.A. Rabbani ${ }^{2}$, S. Hameed ${ }^{1}$, S.R. Pearce ${ }^{3}$ and S.A. Malik ${ }^{1}$ \\ ${ }^{1}$ Department of Biochemistry, Quaid-I-Azam University, \\ Islamabad, Pakistan \\ ${ }^{2}$ Institute of Agri-Biotechnology and Genetic Resources, NARC, \\ Islamabad, Pakistan \\ ${ }^{3}$ School of Life Sciences, University of Sussex, Brighton, United Kingdom \\ Corresponding author: M. Sadia \\ E-mail:munazza_sadia@yahoo.com
}

Genet. Mol. Res. 10 (1): 197-202 (2011)

Received September 27, 2010

Accepted November 12, 2010

Published February 8, 2011

DOI 10.4238/vol10-1gmr1009

\begin{abstract}
A simple protocol for obtaining pure, restrictable and amplifiable megabase genomic DNA from oil-free seed residue of Brassica napus, an important oil seed plant, has been developed. Oil from the dry seeds was completely recovered in an organic solvent and quantified gravimetrically followed by processing of the residual biomass (defatted seed residue) for genomic DNA isolation. The isolated DNA can be cut by a range of restriction enzymes. The method enables simultaneous isolation and recovery of lipids and genomic DNA from the same test sample, thus allowing two independent analyses from a single sample. Multiple micro-scale oil extraction from the commercial seeds gave approximately $39 \%$ oil, which is close to the usual oil recovery from standard oil seed. Most of the amplified fragments were scored in the range of 2.5 to $0.5 \mathrm{~kb}$, best suited for scoring as molecular diagnostics.
\end{abstract}

Key words: Genomic DNA; Lipids; Brassica napus seeds; PCR; RAPD; Restriction analysis 


\section{INTRODUCTION}

Restriction fragment length polymorphism (RFLP) and randomly amplified polymorphic DNA (RAPD) are common molecular approaches employed in plant breeding, genotypic differentiation, gene linkage analysis, assigning evolutionary and taxonomic affinities and relatedness, and DNA fingerprint analysis (Lin et al., 1996). Isolation of pure, restrictable and amplifiable genomic megabase DNA is a limiting step to the development of a reliable method for identifying and utilizing molecular markers. Several methods of DNA isolation are available, and are variants of a few principal protocols (Saghai-Maroof et al., 1984; Dellaporta et al., 1985; Doyle and Doyle, 1987; Webb and Knapp, 1990). Unlike the non-plant DNA protocols, the methods need to be adjusted to each plant species (and even each tissue) due to the myriad of primary and secondary metabolites in plants (Sangwan et al., 1998). Occasionally, even though their co-isolation or contamination might be too low to assay, they may be sufficient to interfere in the analyses of polymorphism. Brassica seeds are rich in lipids (up to $40 \%$ ), which form a visible layer over the tissue homogenate during normal isolation of DNA, and pose difficulty in recovery and further processing of supernatants. Moreover, even traces of lipids may hinder subsequent fingerprinting studies by making the samples hydrophobic and rendering them colloidal through dispersion in reaction cells, adversely affecting the catalysis. Furthermore, in oil seeds, it often becomes necessary to isolate and analyze the oil for quantitation, quality assessment and to compare this to DNA molecular marker data covering genotypic and chemotypic profiling, trait-marker linkage, etc. Obviously, a coupled isolation of the seed oil and the genomic DNA from the same test sample could be highly efficient.

\section{MATERIAL AND METHODS}

\section{Plant material}

Commercial sample of dry (natural) seeds from Brassica napus.

\section{Chemicals}

All reagents and chemicals such as restriction enzymes, dNTPs, Taq polymerase, and agarose were of Sigma (Sigma Chemical Co., USA). Organic solvents were of highest purity grade from E. Merck or Glaxo. Decamer primers of random sequences were from Genosys Systems (USA).

\section{Equipment and supplies}

- Pestle, mortar, sintered funnel (grade 3), microcentrifuge tubes, polymerase chain reaction (PCR) tubes, micropipettes, etc.

- Rotavapor (Buchi, USA)

- PCR machine (Perkin Elmer model 2400)

- Microcentrifuge (Sigma Labozentrifugen, Germany)

- Controlled temperature water bath (Heto Lab. Equipments, Denmark) 
- Electrophoresis system (JICA, Japan)

- UV trans-illuminator and gel documentation system (PDI Inc., USA, with the Diversity Database $^{\mathrm{TM}}$ software)

\section{Solutions required}

- Chloroform:methanol (2:1, v/v)

- $1.0 \%$ sodium chloride solution

-2X CTAB buffer: $100 \mathrm{mM}$ Tris-HCl, pH 8.0, supplemented with 2\% CTAB (w/v), $20 \mathrm{mM}$ EDTA, pH 8.0, 1.4 M NaCl and 1\% (w/v) PVPP

- Chloroform:isoamylalcohol $\left(\mathrm{CHCl}_{3}: \mathrm{IAA}\right)(24: 1, \mathrm{v} / \mathrm{v})$

- $10 \%$ CTAB solution

- $\mathrm{CTAB}$ precipitation reagent: $1 \% \mathrm{CTAB}$ in $50 \mathrm{mM}$ Tris-HCl, $\mathrm{pH} 8.0$, buffer and $10 \mathrm{mM}$ EDTA, pH 8.0

- Salt-TE buffer (STE): 10 mM Tris-HCl, pH 8.0, containing 1 mM EDTA, pH 8.0, and $1 \mathrm{M} \mathrm{NaCl}$

- Light-TE buffer (LTE): 1 mM Tris-HCl, pH 8.0, buffer containing 0.1 mM EDTA, pH 8.0

- Ethanol: absolute

- Concentrated salt solution: $3 \mathrm{M}$ sodium acetate solution

- RNase solution: $3.5 \mathrm{mg}$ per $\mathrm{mL}$ (bovine pancreatic RNase A)

- 50X TAE buffer

\section{Protocol}

\section{Oil extraction}

- Soak $50 \mathrm{mg}$ Brassica seeds in a $\mathrm{CHCl}_{3}: \mathrm{CH}_{3} \mathrm{OH}$ mixture $(2: 1, \mathrm{v} / \mathrm{v})$ for at least $30 \mathrm{~min}$ and then homogenize the seeds in the solvent with a mortar and pestle. Recover the solvent fraction carefully from the crushed seed residue by filtration through a sintered funnel (grade 3).

- Repeat above extraction and recovery of oil in the organic solvent $3 \mathrm{X}$ and pool all solvent fractions.

- Remove water-soluble impurities from the filtrate through Folch washing with one-fifth volume $1 \% \mathrm{NaCl}$ solution (Folch et al., 1957).

- Remove residual moisture, if any, from the solvent fraction by adding solid anhydrous sodium sulfate.

- Evaporate solvent from the lipid extract in a rotary evaporator (Buchi) at $35^{\circ} \mathrm{C}$.

- Quantitate the oil yield (\% of seed dry mass) gravimetrically.

\section{Isolation of DNA}

All steps were carried out at room temperature, unless stated otherwise. The defatted seed residue was dried between two layers of filter paper to remove traces of solvent and then processed for DNA isolation by the CTAB method with some minor modifications:

- Grind the solvent-free seed residue to a fine powder in the presence of liquid nitrogen. 
- Incubate the powder in 3 volumes extraction medium [2X CTAB buffer] in a mi crocentrifuge tube at $65^{\circ} \mathrm{C}$ for $30 \mathrm{~min}$ in a water bath with occasional gentle swirling. - Clarify the extract by centrifugation at $10,000 \mathrm{~g}$ for $15 \mathrm{~min}$ and collect the supernatant.

- Extract the supernatant with an equal volume of chloroform:isoamyl alcohol [24:1] and collect the upper aqueous phase after centrifugation [4000 $\mathrm{g}, 10 \mathrm{~min}$ ].

- Repeat the above extraction after adding $1 / 10$ th volume warm $\left(55^{\circ} \mathrm{C}\right) 10 \% \mathrm{CTAB}$ solution.

- To the aqueous layer recovered above, add at least 1.5 volume of the CTAB precipitation reagent, mix gently, and collect the observed DNA precipitate by centrifugation [4000 $g, 5 \mathrm{~min}] 1$. Sequentially wash the DNA preparation with $100 \mathrm{~mL} 80 \%$ (v/v) absolute ethanol.

- Evaporate ethanol under vacuum and dissolve the pellet in STE.

- Precipitate DNA by adding 2 volumes ethanol and 1/10th volume $3 \mathrm{M}$ sodium acetate solution.

- Dissolve pellet in 25 to $50 \mathrm{~mL}$ LTE and incubate with about $100 \mathrm{mg}$ per $\mathrm{mL}$ (1 to $2 \mathrm{~mL}$ stock solution) of DNase-free RNase $\mathrm{A}$ at $35^{\circ} \mathrm{C}$.

- Extract with $\mathrm{CHCl}_{3}$ :IAA and add 1/10th volume $3 \mathrm{M}$ sodium acetate solution.

- Precipitate with 2 volumes ethanol 2 [(diethylamino)ethanol], wash pellet with $90 \%$ ethanol, dry under vacuum and re-hydrate precipitate in $50 \mathrm{~mL}$ LTE for at least $1 \mathrm{~h}$.

Notes

1. Although precipitates may not be visible, still subject preparation to centrifugation after further addition of 0.5 volumes $\mathrm{CTAB}$ precipitation reagent.

2. Precipitation may be carried out at $-20^{\circ} \mathrm{C}$ overnight.

\section{RAPD analysis}

The PCR mixture, in a total volume of $25 \mathrm{~mL}$, contained $50 \mathrm{ng}$ template DNA, $0.25 \mathrm{U}$ Taq polymerase, $2.5 \mathrm{~mL}$ 10X Taq polymerase buffer, $400 \mathrm{mM}$ dNTPs, $3.5 \mathrm{mM} \mathrm{Mg}{ }^{2+}, 10 \mathrm{pmol}$ 10 -mer primer ( $400 \mathrm{nM}$ ). PCR was run in a GeneAmp PCR System 2400 (Perkin-Elmer) with a pre-PCR cycle of $94^{\circ} \mathrm{C}$ for $5 \mathrm{~min}, 35^{\circ} \mathrm{C}$ for $5 \mathrm{~min}$ and $10^{\circ} \mathrm{C}$ for $15 \mathrm{~min}$ followed by 40 cycles of $94^{\circ} \mathrm{C}$ for $1.5 \mathrm{~min}, 35^{\circ} \mathrm{C}$ for $1.5 \mathrm{~min}, 72^{\circ} \mathrm{C}$ for $1 \mathrm{~min}$, and finally completion of extension at $72^{\circ} \mathrm{C}$ for $5 \mathrm{~min}$.

PCR contents were then kept at $4{ }^{\circ} \mathrm{C}$ until subjected to agarose (1.4\%) electrophoresis in 50X TAE buffer. The amplified fragments were stained with ethidium bromide, visualized under a UV-transilluminator and photographed under a Night Hawk Gel Documentation System equipped with the Diversity Database software ( $p d i$ USA).

\section{Restriction digestion}

The restriction digestion assay mixture in a total volume of $25 \mathrm{~mL}$ contained $10 \mathrm{mg}$ DNA, $1 \mathrm{mg}$ RNase, $3 \mathrm{U}$ restriction enzyme and $2.5 \mathrm{~mL}$ restriction enzyme-specific buffer. Incubation was carried out overnight at $37^{\circ} \mathrm{C}$ except for $\mathrm{BamHI}$ where incubation was at $30^{\circ} \mathrm{C}$. After digestion, the reaction mixture was electrophoresed through $0.8 \%$ agarose in 50X TAE buffer. 


\section{RESULTS AND DISCUSSION}

Prior to DNA isolation, the test seed material was subjected to recovery of the fixed oil. The multiple micro-scale oil extraction from the single commercial lot of the seeds gave an estimate of $39 \%$ oil, which is close to the usual oil recovery from the standard oil seed. Also, the genomic DNA isolated from defatted seed residue when electrophoresed and stained was observed to be of high molecular weight and unsheared (Figure 1, lanes 12 and 13). PCR amplification of the isolated genomic DNA was successful with many primers. Figure 1 shows nine of these PCR amplification profiles displayed by the DNA preparation from one commercial stock of the Brassica oil seeds using 10-mer primers of random sequence. The number of amplicons per primer ranged from 3 to 18 with an average of 7.8 amplicons/primer/template. Most of the amplified fragments were scored in the range of 2.5 to $0.5 \mathrm{~kb}$, best suited for scoring as molecular diagnostics. DNA was completely digested with a number of restriction enzymes. Figure 2 shows the restriction digestion of the purified DNA preparation with a range of restriction enzymes, which included PstI, Sau3AI, BamHI, EcoRI, HindIII, XhoI, and SalI.

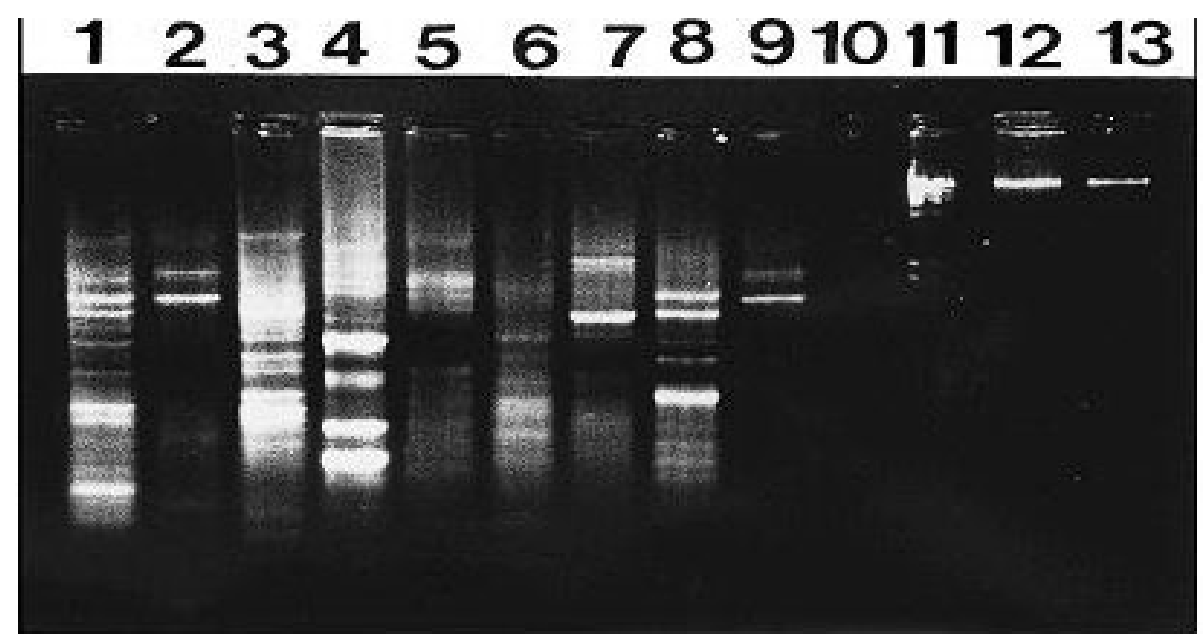

Figure 1. PCR amplification of purified DNA from defatted seeds of Brassica napus using ten different primers. The sequences of primers were: 5'-CGCAGTACTC-3', 5'-GTCCTACTCG-3', 5'-CTACACAGGC-3', 5'-GTGCTTAGCG-3', 5'-GTCCTCAACG-3', 5'-CTACTACCGC-3', 5'-CAGCACCCAC-3', 5' CAGGCCCTTC-3', 5'-CTGATCGTAC-3', 5'-TCCTCACTAG-3' (lanes 1-10, respectively). MW marker was HindIII double digest (lane 11), and defatted undigested seed DNA (lanes 12 and 13).

The combination protocol enables isolation of both DNA and fixed oil from one sample of Brassica seeds and may also be applicable to other oil seeds. The procedure is technically simple, less expensive, and is especially valuable for genetic analyses of oil seeds. PCR-based amplification of DNA is simple but the profiles are highly susceptible to subtle differences in reaction mixture composition, the quality and quantity of template DNA, and amplification conditions. To minimize time and effort, the DNA preparations should be identical with respect to purity, integrity and quantity. There is a good chance of some lipid contamination in the final oil seed DNA preparation, since the tissue is exceptionally rich in lipids. This method could be employed with other medicinal and aromatic plants where the presence of lipids, in particular, is very high. 


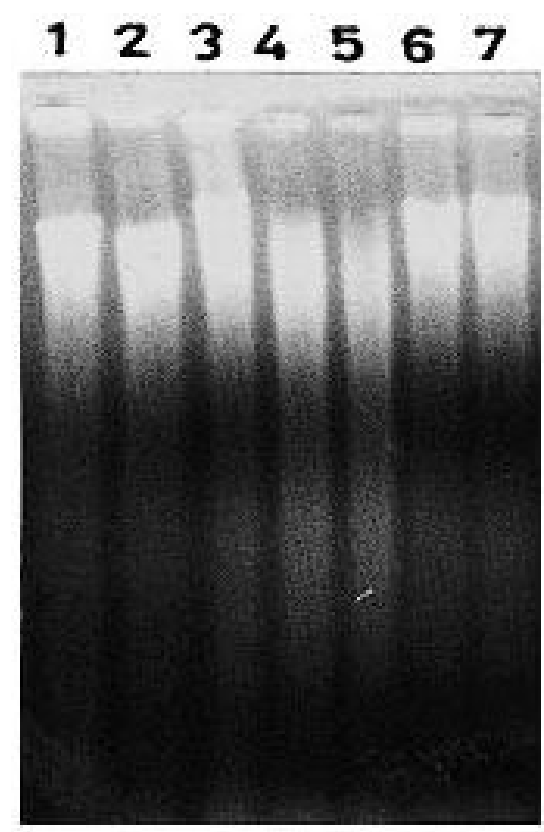

Figure 2. Restriction digestion of purified Brassica napus DNA with restriction enzymes PstI, Sau3AI, BamHI, EcoRI, HindIII, XhoI, and SalI (lanes l-7, respectively).

\section{ACKNOWLEDGMENTS}

The authors are grateful to the Higher Education Commission Pakistan for their financial assistance of the project in the form of a scholarship for M. Sadia.

\section{REFERENCES}

Dellaporta SL, Wood J and Hicks JB (1985). Maize DNA Miniprep. In: Molecular Biology of Plants (Malberg R, Messing J and Sussex I, eds.). Cold Spring Harbor Laboratory Press, Cold Spring Harbor, New York, 36-37.

Doyle JJ and Doyle JL (1987). A rapid DNA isolation procedure for small quantities of fresh leaf tissue. Phytochem. Bull. 19: 11-15.

Folch J, Lees M and Sloane-Staneley GH (1957). A simple method for the isolation and purification of total lipides from animal tissues. J. Biol. Chem. 226: 497-509.

Lin JJ, Kuo J, Ma J, Saunders JA, et al. (1996). Identification of molecular markers in soybean comparing RFLP, RAPD and AFLP DNA mapping technique. Plant Mol. Biol. Rep. 14: 156-169.

Saghai-Maroof MA, Soliman KM, Jorgensen RA and Allard RW (1984). Ribosomal DNA spacer-length polymorphisms in barley: Mendelian inheritance, chromosomal location, and population dynamics. Proc. Natl. Acad. Sci U. S. A. 81: 8014-8018.

Sangwan NS, Sangwan RS and Kumar S (1998). Isolation of genomic DNA from the antimalarial plant Artemisia annua. Plant Mol. Biol. Rep. 16: 1-9.

Webb DM and Knapp SJ (1990). DNA extraction from a previously recalcitrant plant genes. Plant Mol. Biol. Rep. 8: $180-185$. 